Fuji Pratami ${ }^{1}$ Muhammad Danil $^{2}$ Hamdanil $^{3}$

\section{Korelasi Variasi Gaya Mengajar Guru Pendidikan Agama Islam dan Budi Pekerti dengan Hasil Belajar Peserta Didik}

\begin{abstract}
Abstrak
Tujuan penelitian untuk mengetahui korelasi dan hubungan antara variasi gaya mengajar guru Pendidikan Agama Islam dan Budi Pekerti dengan hasil belajar peserta didik kelas XI di SMA N 1 Rambatan Semester Genap T.A 2019/2020. Metode yang digunakan metode korelasional. Hasil korelasi variasi gaya mengajar guru PAI-BP dengan hasil belajar PAI-BP peserta didik kelas XI di SMA N 1 Rambatan : tidak terdapat korelasi yang signifikan antara penerapan variasi gaya mengajar dengan hasil belajar PAI-BP peserta didik kelas XI di SMA N 1 Rambatan. Hasil penelitian : korelasi variasi gaya mengajar dengan hasil belajar terdapat harga $\mathrm{r}_{\mathrm{xy}}$ sebesar $-0,114$, dilihat pada tabel indek korelasi ' $\mathrm{r}$ ' product moment pada kelas interval 0,00 0,20 dinyatakan dengan harga $r_{x y}$ dengan interpretasi variasi gaya mengajar dan hasil belajar peserta didik terdapat korelasi, akan tetapi sangat lemah atau rendah. variasi gaya mengajar guru pendidikan agama Islam memberikan konstribusi terhadap hasil belajar PAI-BP peserta didik di SMA N 1 Rambatan sebesar 1,3\%, sedangkan sisanya 98,7\% berasal dari variabel lain yang tidak termasuk dalam penelitian.
\end{abstract}

Kata Kunci: Variasi Gaya Mengajar, Guru PAI-BP, Hasil Belajar.

\begin{abstract}
The research objective was to determine the correlation and relationship between variations in teaching styles of Islamic Religious Education teachers and Character and the learning outcomes of class XI students at SMA N 1 Rambat even Semester T.A 2019/2020. The method used is the correlation method. Correlation results of variations in teaching styles of PAI-BP teachers with PAI-BP learning outcomes of class XI students at SMA N 1 Rambat: there is no significant correlation between the application of variations in teaching styles with the learning outcomes of PAI-BP for class XI students at SMA N 1 Rambat. The results of the study: the correlation of variations in teaching styles with learning outcomes has a rxy price of -0.114 , seen in the correlation index table " $r$ 'product moment in the class interval from 0.00 to 0.20 expressed by the price with the interpretation of variations in teaching styles and learning outcomes of students. there is a correlation, but it is very weak or low. variations in teaching styles of Islamic religious education teachers contributed $1.3 \%$ to the learning outcomes of PAI-BP students at SMA N 1 Rambat, while the remaining $98.7 \%$ came from other variables not included in the study.
\end{abstract}

Keywords: Variations in Teaching Styles, PAI-BP Teachers, Learning Outcomes.

\footnotetext{
${ }^{1}$ Program Studi Pendidikan Agama Islam, STAIN Mandailing Natal

email : fujipratami@stain-madina.ac.id

${ }^{2}$ Program Studi Hukum Ekonomi Syariah, STAIN Mandailing Natal

email : $\underline{\text { mdanil@ @tain-madina.ac.id }}$

${ }^{3}$ Program Studi Hukum Ekonomi Syariah, STAIN Mandailing Natal

email : hamdanil@stain-madina.ac.id
} 


\section{PENDAHULUAN}

Pendidikan ditingkatkan kualitasnya dengan peningkatan potensi akademik atau hasil belajar peserta didik secara menyeluruh. Meningkatnya hasil belajar dari aspek kognitif, psikomotor dan afektif. Akhir dari proses pendidikan adalah anak memiliki kekuatan spiritual keagamaan, pengendalian diri, kepribadian, kecerdasan, akhlak mulia, serta keterampilan yang diperlukan dirinya, masyarakat, bangsa dan negaranya (Sanjaya, 2007:3). Proses pendidikan harus berjalan sesuai tujuan pendidikan yang hendak dicapai. Agar tercapainya tujuan tersebut, maka guru harus memiliki keterampilan dasar mengajar (Djamarah, 2000:38). Penggunaan variasi gaya mengajar merupakan salah satu keterampilan guru supaya suasana pembelajaran menjadi menyenangkan, efektif dan efisien (Junaidah, Anis. Hairunisya, 2018:p.4).

Guru bertanggung jawab membimbing dan mengarahkan peserta didik untuk perkembangan jasmani dan rohani menuju tingkat kedewasaan sehingga dapat menjalankan tugasnya sebagai pendidik dan pengasuh (UU No. 14 Tahun 2005). Mata pelajaran Pendidikan Agama Islam dan Budi Pekerti merupakan pembelajaran yang mencakup aspek keagamaan yang harus dilakukan peserta didik dalam memahami pengetahuan agamanya dan mengaktualisasikannya dalam tindakan nyata (Ghozaly, 2016:iii). Hasil belajar dapat dilihat dengan adanya perubahan tingkah laku pada diri seorang peserta didik yang dapat diamati dan diukur dalam bentuk pengetahuan, sikap dan keterampilan (Hamalik, 2010:3). Guru, peserta didik dan orang tua mengharapkan ketercapaian tujuan pendidikan dan pembelajaran serta perolehan hasil belajar di atas Kriteria Ketuntasan Minimal (KKM).

Berdasarkan permasalahan yang peneliti temukan di SMA Negeri 1 Rambatan hasil belajar peserta didik masih ada yang dibawah KKM. Data hasil belajar diawal ini peneliti dapatkan dari rata-rata perolehan nilai Penilaian Harian (PH) peserta didik Kelas XI pada mata pelajaran Pendidikan Agama Islam dan Budi Pekerti di Semester Genap Tahun Pelajaran 2019/2020. KKM mata pelajaran Pendidikan Agama Islam dan Budi Pekerti Kelas XI adalah 75. Sebenarnya variasi gaya mengajar yang diterapkan oleh guru belum konsisten. Rumusan masalah penelitian ini adalah apakah terdapat korelasi atau hubungan antara variasi gaya mengajar guru PAI-BP dengan hasil belajar peserta didik kelas XI di SMA Negeri 1 Rambatan?. Tujuan penelitian untuk mengetahui korelasi dan hubungan antara variasi gaya mengajar guru PAI-BP dengan hasil belajar peserta didik kelas XI di SMA N 1 Rambatan Semester Genap T.A 2019/2020.

Temuan terdahulu oleh Dian Yulianti, 2018 judul artikel Hubungan antara Gaya Mengajar Guru dengan Prestasi Belajar Bahasa Indonesia dengan tempat penelitian di MTs Negeri 2 Ciamis pada Jurnal Diksatrasia. Tujuan penelitian untuk mengetahui hubungan antara gaya mengajar guru dengan prestasi belajar Bahasa Indonesia peserta didik di MTs Negeri 2 Ciamis. Metode yang digunakan adalah metode penelitian deskriptif dan analisis korelasi untuk mengetahui hubungan antar variabel. Hasil penelitian : (1) Gaya mengajar guru termasuk dalam kategori baik dengan rata-rata nilai responden sebesar 258. (2) Prestasi belajar bahasa Indonesia peserta didik kelas VII MTs Negeri 2 Ciamis termasuk kategori baik pada nilai rapor dengan rata-rata nilai 78 dengan KKM 65. (3) Terdapat hubungan yang sangat kuat antara gaya mengajar guru dengan prestasi belajar Bahasa Indonesia MTs Negeri 2 Ciamis. Berdasarkan hasil uji korelasi sebesar 0,81. Uji $t$ pada tingkat kepercayaan 0.05 diperoleh $t_{\text {hitung }}>t_{\text {tabel }} 11,299$ $>$ 1,667 (Yulianti, 2018:p.1). Persamaan dengan penelitian yang penulis lakukan adalah mempunyai tujuan penelitian yang sama, yaitu untuk mengetahui hubungan gaya mengajar guru dengan prestasi belajar/hasil belajar peserta didik/peserta didik. Perbedaan terletak pada mata pelajaran serta sedikit metode penelitian. 
Temuan Kusmaryono dan Ulia, 2020 dengan judul artikel Interaksi Gaya Mengajar dan Konten Matematika sebagai Faktor Penentu Kecemasan Matematika pada Jurnal Mosharafa : Jurnal Pendidikan Matematika. Tujuan penelitian untuk menyelidiki seberapa besar dampak gaya mengajar guru terhadap kecemasan matematika pada peserta didik jurusan IPA dan IPS serta menyelidiki adanya interaksi antara konten matematika dan gaya mengajar guru dalam menentukan tingkat kecemasan matematika peserta didik. Hasil penelitian (1) Gaya mengajar guru dengan PBL memiliki dampak terhadap penurunan kecemasan matematika pada peserta didik di semua jurusan IPA dan IPS, secara statistik signifikan $(p<0,05)$ dan secara praktis signifikan dengan dampak (efek) masing-masing $d=0,84$ dan $d=0,55$, dan (2) Terdapat interaksi yang berarti antara konten matematika dan gaya mengajar guru dalam menentukan tingkat kecemasan matematika dengan $(\mathrm{p}<0,05)$ signifikasi (Kusmaryono, Imam. Ulia, 2020:p.1). Persamaan dengan penelitian yang penulis lakukan adalah sama-sama membahas tentang gaya mengajar. Perbedaan dengan penelitian yang penulis lakukan adalah pada mata pelajaran.

\section{METODE}

Metode yang digunakan pada penelitian ini adalah metode korelasional yaitu metode yang digunakan untuk mencari hubungan antara dua variabel atau lebih (Sudijono, 2005:167). Hubungan variabel variasi gaya mengajar guru PAI-BP dengan hasil belajar peserta didik kelas XI di SMA N 1 Rambatan. Populasi adalah sebanyak 162 orang peserta didik. Sampel penulis menggunakan rumus dari Taro Yumane (Riduwan, 2005:93). Presisi yang penulis tetapkan adalah 10\%. Maka jumlah sampelnya adalah $n=\frac{N}{N \cdot d^{2}+1}=\frac{162}{162 \cdot 0,1^{2}+1}=\frac{162}{162 \cdot 0,01+1}=61,83=62$.

Perolehan data tentang korelasi Variasi Gaya Mengajar dengan Hasil Belajar Peserta didik Kelas XI di SMA N 1 Rambatan. Penelitian menggunakan angket dengan skor 1-5. Teknik analisi data adalah teknik korelasional Pearson Product Moment (r). Rumus yang digunakan adalah:

$r_{x, y}=\frac{n\left(\sum \mathrm{XY}\right)-\left(\sum \mathrm{X}\right)\left(\sum \mathrm{Y}\right)}{\sqrt{\left\{n \cdot \sum \mathrm{X}^{2}-\left(\sum \mathrm{X}\right)^{2}\right\}} \cdot\left\{n \sum \mathrm{Y}^{2}-\left(\sum \mathrm{Y}\right)^{2}\right\}}$

Tahapan-tahapan yang penulis lakukan dalam menganalisis data adalah: (1) Membuat Ha dan Ho dalam bentuk kalimat. (2) Membuat Ha dan Ho dalam bentuk statistik. (3) Membuat tabel penolong untuk menghitung korelasi Product moment. (4) Mencari $\mathrm{t}_{\text {hitung }}$ dengan rumus (Arikunto, 2005:98) :

$r_{x, y}=\frac{n\left(\sum \mathrm{XY}\right)-\left(\sum \mathrm{X}\right)\left(\sum \mathrm{Y}\right)}{\sqrt{\left\{n \cdot \sum \mathrm{X}^{2}-\left(\sum \mathrm{X}\right)^{2}\right\}} \cdot\left\{n \sum \mathrm{Y}^{2}-\left(\sum \mathrm{Y}\right)^{2}\right\}}$

Tingkat hubungan masing masing variabel bebas dengan variabel terkait digunakan interpretasi terhadap koefisien korelasi. Mencari besarnya sumbangan (Konstribusi) variabel X dan $\mathrm{Y}$ dengan menggunakan rumus: $\mathrm{KP}=\mathrm{r}^{2} \mathrm{x} 100 \%$. Setelah harga $\mathrm{r}$ diperoleh, kemudian dilakukan uji keberartian korelasi (uji signifikansi) dengan menggunakan uji t. Setelah diperoleh

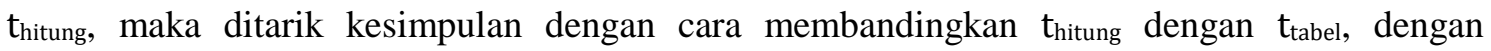
ketentuan: (a) Jika $t_{\text {hitung }} \geq t_{\text {tabel }}$, maka $\mathrm{H}_{0}$ ditolak, artinya terdapat hubungan yang signifikan antara variasi gaya mengajar guru PAI-BP dengan hasil belajar peserta didik kelas XI SMA N 1 Rambatan. (b) Jika $t_{\text {hitung }} \leq t_{\text {tabel }}$, maka $\mathrm{H}_{0}$ diterima, artinya tidak terdapat hubungan yang signifikan antara variasi gaya mengajar guru PAI-BP dengan hasil belajar peserta didik kelas XI SMA N 1 Rambatan. 


\section{HASIL DAN PEMBAHASAN}

Deskripsi data tentang variasi gaya mengajar guru PAI-BP pada Kelas XI di SMA N 1 Rambatan dari 62 orang sampel Skor tertinggi yang diperoleh oleh peserta didik adalah 129. Sedangkan skor terendah yang diperoleh oleh peserta didik adalah 77. Variasi gaya mengajar berada pada tingkatan antara 78 - 101 dengan kategori sedang. Deskripsi data tentang hasil belajar PAI-BP peserta didik kelas XI SMA N 1 Rambatan., nilai tertinggi kelas XI di SMA N 1 Rambatan adalah 86 dan nilai terendah adalah 44. Untuk mengetahui tinggi rendahnya hasil belajar peserta didik kelas XI di SMA N 1 Rambatan, maka dapat ditentukan meannya denga menggunakan rumus sebagai berikut: $\frac{\sum X}{N}=\frac{4268}{62}=68,83$ Secara keselurukan tingkat pencapaian hasil belajar peserta didik kelas XI di SMA N 1 Rambatan sebesar 68,83 dengan klasifikasi tinggi.

\section{Uji Normalitas}

Uji normalitas data menggunakan software minitab.14. Hasil dari uji normalitas angket dinyatakan berdistribusi normal apabila nilai $p$-Value $>\alpha$. Taraf signifikansi ( $\alpha$ yang penulis gunakan adalah $10 \%(0,10)$. Nilai $p$-Value dengan menggunakan uji kenormalan Ryan-Joiner adalah $>0,10$. Jadi dapat disimpulkan bahwa data angket berdistribusi normal. Hasil dari uji normalitas hasil belajar adalah $P$-Value untuk uji normalitas hasil belajar juga $>0,10$. Jadi, dapat disimpulkan bahwa data hasil belajar juga berdistribusi normal.

\section{Uji Homogenitas}

Uji homogenitas menggunakan software minitab.14. Hasil uji homogenitas untuk data angket dinyatakan homogen apabila nilai $p$-Value $>\alpha$. Taraf signifikansi $(\alpha)$ yang penulis gunakan adalah $10 \%(0,10)$. Berdasarkan uji Bartlett diperoleh $p$-Value $=0,708>0,10$. Jadi dapat disimpulkan bahwa data angket bersifat homogen. Hasil dari uji homogenitas hasil belajar adalah $p$-Value dari uji Bartlett Test $=0,438>0,10$. Jadi data angket bersifat homogen.

Korelasi antara variasi gaya mengajar guru terhadap hasil belajar peserta didik kelas XI di SMA N 1 Rambatan, dapat dilihat pada tabel dibawah ini :

Tabel 2. Hasil Pencarian Korelasi Variasi Gaya Mengajar dengan Hasil Belajar Menggunakan Program SPSS

\begin{tabular}{|c|c|c|c|}
\hline \multicolumn{4}{|c|}{ Correlations } \\
\hline & & Gaya Mengajar Guru & Hasil Belajar \\
\hline \multirow{3}{*}{$\begin{array}{l}\text { Gaya } \\
\text { Mengajar } \\
\text { Guru }\end{array}$} & Pearson Correlation & 1 & -.114 \\
\hline & Sig. (2-tailed) & & .376 \\
\hline & $\mathrm{N}$ & 62 & 62 \\
\hline \multirow[t]{3}{*}{ Hasil Belajar } & Pearson Correlation & -.114 & 1 \\
\hline & Sig. (2-tailed) & .376 & \\
\hline & $\mathrm{N}$ & 62 & 62 \\
\hline
\end{tabular}

Berdasarkan data diatas diperoleh nilai $\left(r_{x y}\right)$ adalah $-0,114$. Hasil pengujian ' $r$ ' diperoleh harga persaratan dari nilai $r_{x y}$ sebesar $-0,114$ dan selanjutnya dilihat pada tabel indek korelasi " $r$ ' product moment pada kelas interval 0,00-0,20 dinyatakan dengan harga $r_{x y}$ dengan interpretasi antara variabel $\mathrm{X}$ dan variabel $\mathrm{Y}$ memang terdapat korelasi, akan tetapi korelasi itu sangat lemah ( dianggap tidak ada korelasi antar variabel $\mathrm{X}$ dan variabel $\mathrm{Y}$ ). 


\section{Pengujian Hipotesis}

Penelitian ini bertujuan mengetahui apakah antara variabel $\mathrm{X}$ dan variabel $\mathrm{Y}$ terdapat korelasi yang signifikan, untuk itu dirumuskan Hipotesis alternatif (Ha) dan Hipotesis nihil (Ho). Ketentuannya bila $t_{\text {hitung }}$ lebih besar dari $t_{\text {tabel }}$ maka (Ha) diterima dan (Ho) ditolak, kalu $t_{\text {hitung }}$ sama persis dengan $t_{\text {tabel }}$ maka (Ho) diterima. Berdasarkan perhitungan diatas, diperoleh $t_{\text {hitung }}$ sebesar 0,013 , selanjutnya interpretasi terhadap $t_{\text {hitung }}$ tersebut df 60 , dilihat dalam $t_{\text {tabel }}$ pada urutan yang 60 diperoleh taraf $5 \%=0,254$ dan taraf $1 \%=0,330$ sedangkan $t_{\text {hitung }} 0,013$ ternyata $t_{\text {hitung }}$ kecil dari $t_{\text {tabel }}$ pada taraf $5 \%$ dan pada taraf $1 \% t_{\text {hitung }}$ juga kecil dari $t_{\text {tabel }}$. Pada taraf $5 \%$ hipotesis yang diterima adalah (Ha) artinya tidak terdapat hubungan yang signifikan antara antara variasi gaya mengajar guru PAI-BP terhadap hasil belajar peserta didik pada kelas XI di SMA N 1 Rambatan. Berdasarkan hasil analisis, $t_{\text {hitung }}$ adalah kecil dari $t_{\text {tabel }}$ pada taraf signifikan 5\% dengan demikian dapat dinyatakan (Ha) ditolak dan (Ho) diterima, sedangkan pada taraf $1 \% t_{\text {hitung }}$ kecil dari $t_{\text {tabel }}$ Maka (Ha) ditolak dan (Ho) diterima. Maka disimpulkan bahwa pada taraf 5\% tidak terdapat hubungan yang positif antara Variasi Gaya mengajar Guru PAI-BP dengan hasil belajar peserta didik pada kelas XI di SMA N 1 Rambatan. Sedangkan pada taraf $1 \%$ juga tidak terdapat hubungan yang positif antara Variasi Gaya mengajar Guru PAI-BP dengan hasil belajar peserta didik pada kelas XI di SMA N 1 Rambatan. Nilai korelasi $r_{x y}$ sebesar 0,114 diatas diperoleh koofesien determinannya sebesar $1,30 \%$ disimpulan bahwa variabel variasi gaya mengajar guru PAI-BP memberikan konstribusi pada hasil belajar PAI-BP peserta didik di SMA N 1 Rambatan sebesar 1,30\%, sedangkan sisanya $98,70 \%$ dari variabel lain.

Para ahli pendidikan sepakat penerapan variasi gaya mengajar dapat mempertinggi hasil belajar peserta didik (Setiyaningsih dkk, 2020:p.1). Penerapan variasi gaya mengajar terhadap hasil belajar peserta didik pada mata pelajaran PAI-BP haya sedikit memberikan konstribusi terhadap hasil belajar peserta didik kelas XI di SMA N 1 Rambatan dengan koofesien determinan 1,30\% dan sisanya 98,70\% dipengaruhi variabel lain. Agar peserta didik dapat mencapai hasil belajar yang baik tentu sangat diperlukan peran besar seorang guru (Prasela dkk, 2020:p.3). Guru membimbing peserta didik tanpa membebani peserta didik (Ekawati dkk, 2019:p.1). Variasi gaya mengajar yang diterapkan itu memberikan konstribusi atau pengaruh yang rendah terhadap hasil belajar peserta didik berdasarkan temuan di SMA N 1 Rambatan, karna dipengaruhi komponen lain. Variasi dapat mengurangi gangguan proses pembelajaran (Supardi, 2009:126). Guru yang tidak mampu menerapkan variasi gaya mengajar maka peserta didik diharapkan menguasai kompetensi materi ajar (Junaidah, Anis. Hairunisya, 2018:p.3). Jadi untuk memaksimalkan hasil belajar peserta didik harus ada keterkaitan antara guru dan peserta didik.

\section{UCAPAN TERIMA KASIH}

Ucapan terima kasih disampaikan kepada Kepala Sekolah SMA Negeri 1 Rambatan, guru Pendidikan Agama Islam dan Budi Pekerti Kelas XI dan peserta didik Kelas XI.

\section{SIMPULAN}

Hasil korelasi variasi gaya mengajar guru Pendidikan Agama Islam dengan hasil belajar PAI-BP peserta didik kelas XI di SMA N 1 Rambatan yaitu: tidak terdapat korelasi yang signifikan antara penerapan variasi gaya mengajar dengan hasil belajar PAI-BP peserta didik kelas XI di SMA N 1 Rambatan. Dilihat pada hasil penelitian yaitu: korelasi variasi gaya 
mengajar dengan hasil belajar terdapat harga $\mathrm{r}_{\mathrm{xy}}$ sebesar $-0,114$, dilihat pada tabel indek korelasi " $r$ ' product moment pada kelas interval 0,00-0,20 dinyatakan dengan harga $r_{x y}$ dengan interpretasi variasi gaya mengajar dan hasil belajar pendidkan agama Islam peserta didik terdapat korelasi, akan tetapi sangat lemah atau rendah. variasi gaya mengajar guru pendidikan agama Islam memberikan konstribusi terhadap hasil belajar PAI-BP peserta didik di SMA N 1 Rambatan sebesar $1,3 \%$, sedangkan sisanya $98,7 \%$ berasal dari variabel lain yang tidak termasuk dalam penelitian.

\section{DAFTAR PUSTAKA}

Djamarah, S. B. (2000). Guru dan Anak Didik dalam Interaksi Edukatif. Jakarta : PT. Rineka Cipta.

Ekawati, Mona. Nevi, Y. (2019). Teori Belajar Berdasarkan Aliran Psikologi Humanistik dan Implikasi Pada Proses Belajar Pembelajaran. JRPP, 2(2), 266-269. https://journal.universitaspahlawan.ac.id/index.php/jrpp/article/view/482/727

Ghozaly, F. (2016). Buku Guru Pendidikan Agama Islam dan Budi Pekerti. Jakarta : Kementerian Pendidikan dan Kebudayaan.

Hamalik, O. (2010). Kurikulum dan Pembelajaran. Jakarta : PT. Bumi Aksara.

Junaidah, Anis. Hairunisya, N. (2018). Pengaruh Gaya Mengajar, Model Pembelajaran STAD dan Motivasi Belajar Siswa terhadap Prestasi Belajar IPS. Inspirasi, 39-46. http://jurnal.stkippgritulungagung.ac.id/index.php/inspirasi/article/view/408/349

Kusmaryono, Imam. Ulia, N. (2020). Interaksi Gaya Mengajar dan Konten Matematika sebagai Faktor Penentu Kecemasan Matematika. Mosharafa, 9(1), 143-154. https://journal.institutpendidikan.ac.id/index.php/mosharafa/article/view/mv9n1_13/563

Prasela, Nova. Witarsa, Ramdhan. Ahmadi, D. (2020). Kajian Literatur tentang Hasil Belajar Kognitif Menggunakan Model Pembelajaran Langsung Siswa Sekolah Dasar. JRPP, 3(2), 209-216. https://journal.universitaspahlawan.ac.id/index.php/jrpp/article/view/1218/962

Riduwan. (2005). Belajar Mudah Penelitian untuk Guru, Karyawan dan Peneliti Pemula. Bandung : Alfabeta.

Sanjaya, W. (2007). Starategi Pembelajaran Berorientasi Standar Proses Pendidikan (2nd ed.). Jakarta : Kencana.

Setiyaningsih, Suhelin. Sunarso, A. (2020). Hubungan Variasi Mengajar Guru dan Motivasi Belajar Siswa dengan Hasil Belajar Matematika. JLJ, 9(2), 66-71. https://journal.unnes.ac.id/sju/index.php/jlj/article/view/39313/17643

Sudijono, A. (2005). Pengantar Statistik Pendidikan. Jakarta : PT. Gafindo Persada.

Supardi. (2009). Profesi Keguruan. Jakarta : UIN Jakarta Press.

Yulianti, D. (2018). Hubungan antara Gaya Mengajar Guru dengan Prestasi Belajar Bahasa Inndonesia. Diksatrasia, 2(1), 1-11. http:/1338-8241-1-PB.pdf 